\title{
Menedžment talentov za potrebe industrije 4.0
}

\author{
Janja Polenšek Davidovski* \\ Geberit proizvodnja d. o. o., Bezena 55a, 2342 Ruše, Slovenija \\ janja.polensekdavidovski@geberit.com
}

\begin{abstract}
Maja Meško
Univerza na Primorskem, Fakulteta za menedžment, Cankarjeva ulica 5, 6000 Koper, Slovenija maja.mesko@fm-kp.si

Borut Likar

Univerza na Primorskem, Fakulteta za menedžment, Cankarjeva ulica 5, 6000 Koper, Slovenija borut.likar@fm-kp.si
\end{abstract}

\begin{abstract}
Povzetek:
Raziskovalno vprašanje (RV): Kakšne spremembe prinaša industrija 4.0 v praksi menedžmenta talentov?

Namen: Namen raziskave je narediti pregled literature, t. j. znanstvenih člankov, znanstvenih prispevkov s konferenc in samostojnih prispevkov v znanstvenih monografijah s področja menedžmenta talentov v industriji 4.0 in narediti klasifikacijo njihovih karakteristik.

Metoda: Za namen raziskave smo naredili sistematičen pregled literature prispevkov, ki so objavljeni v bazi Scopus.

Rezultati: Na temo menedžmenta talentov in industrije 4.0 je bilo od leta 2011 objavljeno relativno malo prispevkov. Prispevki, ki so objavljeni, obravnavajo kompetence, ki jih bodo potrebovali ključni kadri v prihodnosti, izzive izobraževalnega sistema zaradi sprememb, ki jih terja industrija 4.0, in pomembnost talentov za organizacije prihodnosti.

Organizacija: Pregled znanstvene literature s področja menedžmenta talentov in industrije 4.0 organizacijam daje koristne informacije o trendih na področju kadrovskega menedžmenta.

Družba: Talenti predstavljajo enega izmed ključnih virov razvoja industrije 4.0. Talenti v družbi so nujni, saj prinašajo znanja spreminjajočemu se okolju, prav tako pa tudi konkurenčne prednosti organizacijam.

Originalnost: Raziskava ponuja poglobljen vpogled v spremembe, ki jih industrija 4.0 prinaša $\mathrm{k}$ praksi menedžmenta talentov.

Omejitve/nadaljnje raziskovanje: Omejitev pregleda literature je popolnoma odvisna od predhodno objavljenih raziskav in njihove razpoložljivosti.
\end{abstract}

Ključne besede: menedžment, talenti, menedžment talentov, industrija 4.0. 


\section{Uvod}

Živimo v času največjih sprememb človeškega obstoja. Obdobje četrte industrijske revolucije temelji na hitrem razvoju tehnologije in digitalizacije, ki vplivata na gospodarske, družbene ter kulturne spremembe. Razvoj tehnologije omogoča gospodarsko rast, a na drugi strani povzroča neugoden vpliv na trg dela, saj nove tehnologije spreminjajo naravo dela na vseh delovnih področjih in poklicih. Sinonim za četrto industrijsko revolucijo, industrija 4.0, je z vsemi svojimi spremembami ustvarila velik razkorak med kompetencami zaposlenih in hitro spreminjajočimi se zahtevami njihovih delovnih mest (Whysall et al., 2019). Podjetja, ki bodo izkoristila nove tehnologije in koncepte, ki jih industrija 4.0 prinaša in tako hkrati ustvarjala priložnosti za njihove zaposlene, bodo v veliki prednosti. Strokovnjaki s področja razvoja kadrov so poudarili potrebo po novih in učinkovitejših kadrovskih strategijah. S spremembo narave dela se od posameznika vedno bolj zahtevajo različna znanja in veščine. Znatnega števila delovnih mest, ki obstajajo danes, v prihodnje verjetno ne bo več, zato je pomembno, da se v ustvarjanje prihodnje delovne sile ne vključujejo samo privabljanja, zaposlovanja in razvijanja novih potrebnih talentov, ampak tudi prekvalifikacije sedanjih zaposlenih s programi usposabljanja. Preoblikovanje delovnih procesov za zmanjšanje neusklajenosti kvalifikacij med delovnimi mesti in zaposlenimi bo za podjetja pomembna naloga $\mathrm{v}$ prihodnosti. Mlajše generacije naj se izobražujejo v skladu z zahtevami prihodnjih delovnih mest. OECD je že leta 2010 ugotovila, da se morajo izobraževalni sistemi prilagoditi hitremu razvoju gospodarstva in mladim omogočiti razvoj tistih veščin, ki jim bodo pomagale, da bodo pri svojem delu čim bolj učinkoviti (Belak et al., 2017, str. 12). V času industrije 4.0 je inovacija temeljni koncept, kjer ne gre samo za razvoj s tehnološkega vidika, ampak da podjetja razvijejo tudi nove strateške pristope za celostno upravljanje s kadri. Pomembno je, da se soočijo z izzivi menedžmenta talentov. Razvoj znanja in kompetenc, povezanih z novimi tehnologijami in procesi industrije 4.0, je ključnega pomena pri oblikovanju strategij menedžmenta talentov (Whysall et al., 2019, str. 1, Karacay, 2018, str. 126).

Namen raziskave je narediti klasifikacijo karakteristik literature na temo menedžmenta talentov v času četrte industrijske revolucije. Želimo tudi ugotoviti, kakšne spremembe prinaša industrija 4.0 $\mathrm{v}$ praksi menedžmenta talentov.

\section{Teoretična izhodišča}

Živimo v 21. stoletju, ko se svet spreminja bolj in hitreje, kot kdaj koli prej. Priča smo velikemu tehnološkemu razvoju, ki vpliva na preobrazbo celotnega človeštva, saj spreminja naš način življenja, dela, razmišljanja in komuniciranja. Govorimo o paradigmi industrijske revolucije. Vsem so skupne tehnološke spremembe in inovacije v industriji, ki so jih povzročile mehanizacija (1. industrijska revolucija), uporaba električne energije (2. industrijska revolucija) in elektronika ter avtomatizacija (3. industrijska revolucija). Zdaj smo na razmahu četrte industrijske revolucije, ki temelji na razvoju digitalnih tehnologij in robotike. $Z$ razliko od vseh drugih industrijskih revolucij je bila ta napovedana in ne le opazovana. Vizijo četrte industrijske revolucije so poimenovali industrija 4.0, in sicer jo je nemška vlada predstavila leta 2011 na Hannovrskem sejmu kot del 
strategije visoko tehnološkega razvoja za celotno državo in njihova podjetja (Yun-Hisiang, 2018, str. 315).

Temeljno izhodišče razvoja industrije 4.0 je vzpostavitev pametnih tovarn, ki bodo sposobne učinkovito povezati procese znotraj nje z uporabo interneta stvari (angl. IoT), interneta storitev (angl. $I o S$ ) in kibernetiko fizičnega sistema - ljudi (angl. CPS) ter bodo pri tem koristile veliko količino podatkov (angl. Big Data), ki omogočajo, da lahko v tovarnah v realnem času predvidijo morebitne okvare in posledično načrtujejo prilagoditve spremenjenim razmeram. Vse našteto lahko s pravilnim povezovanjem hitro in varno pripomore industriji ter podjetjem do novih poslovnih modelov. Z njimi se bodo dosegali boljši rezultati na področju optimizacije delovnih procesov, produktivnosti zaposlenih in izdelkov. Vse to zahteva spremenjen način dela, saj bo digitalizacija podjetja uspešna takrat, ko bo uporaba digitalnih rešitev pri zaposlenih spodbudila ustvarjalnost in inovacije (Schwab, 2016, str. 56, Benešová et al., 2017, str. 2196).

Vse revolucije v preteklosti so vplivale na več segmentov družbe, kot so proizvodnja, trg dela in izobraževalni sistem. Zaradi teh sprememb so nekateri poklici in delovna mesta izginili. Nekaterih poklicev, ki obstajajo danes, morda čez nekaj let sploh ne bo več (Baygin, 2016 v Benešová et al., 2017, str. 2196). Potrebe po bolj načrtnem razvijanju delovne sile prinašajo nove zahteve podjetjem, vodstveni politiki in državnim vladam. V času industrije 4.0 morajo organizacije razvijati svojo prihodnjo delovno silo ob sprejemanju novih poslovnih modelov in organizacijskih struktur. Ustvarjanje delovne sile v prihodnosti ne vključuje samo privabljanj, zaposlovanj in razvijanj novih potrebnih talentov, ampak tudi prekvalifikacije sedanjih zaposlenih s programi usposabljanja. Delovna mesta bodo zahtevala še širši spekter znanja, zato se bodo vloge zaposlenih spreminjale $\mathrm{v}$ smislu vsebine in delovnih procesov. Prav tako se bodo danes najmlajše generacije in prihodnji zaposleni morali izobraževati v skladu z zahtevami prihodnjih delovnih mest. Za razvoj znanj in veščin prihodnjih zaposlenih se spodbuja sodelovanje med industrijo ter vzgojno izobraževalnimi ustanovami (srednje šole in fakultete), ki pripravljajo mlade na vstop na trg dela (Karacay, 2018, str. 130-131).

Trenutna tehnološka revolucija ne sme postati dirka med ljudmi in stroji, ampak priložnost, da ljudje preko dela prepoznajo in razvijejo svoj talent. Pri tem je ključno, da podjetja aktivno sodelujejo pri prekvalifikaciji, od posameznikov pa se zahtevata proaktivni pristop in vseživljenjsko učenje.

Talent lahko prinese konkurenčno prednost podjetjem in je ključnega pomena pri vpeljevanju industrije 4.0. Posameznik velja za talentiranega, ko ima potrebna znanja in preplet lastnosti, ki ga delajo izjemnega (Yun \& Yeh, 2018, str. 316). Talent in menedžment talentov sta postala zanimiva po objavi članka v časopisu Mckinsey\& Co consultants z naslovom The War for Talent. Od takrat talent pogosto imenujejo tudi človeški kapital (Karacay, 2018, str. 124).

Opredelitev talenta $\mathrm{v}$ hitro se spreminjajočem industrijskem okolju je težja, kot je bilo to $\mathrm{v}$ preteklosti. Težko je posplošiti merila za opravljanje določenega dela, potrebna znanja in lastnosti posameznikov, saj se podjetja med sabo razlikujejo in zato težko govorimo o enotni opredelitvi 
pojma talent. Definicija Urlicha in Smallwooda (navedeno v Karacay 2018, str. 131) pojem talent opisuje nekoliko širše:

》Talent $=$ kompetenca [znanje, spretnosti in vrednote, potrebne za današnje in jutrišnje delo; prave spretnosti, pravo mesto, pravo delo, pravi čas] prispevek [pripravljen za delo] prispevek [iskanje smisla in namena $v$ svojem poslu].«

Sinonim za uspešen menedžment talentov je geslo: »Pravi ljudje na pravem mestu« (Al Ariss et al., 2014, str. 178). Talent prinaša s seboj dodano vrednost, naloga organizacije pa je, da ustvari spodbudno okolje, da posameznik svoj talent razvije (Gallardo-Gallardo et al., 2013, str. 269-270). Prepoznavanje talentov je zato postala glavna prednostna naloga organizacij v industriji 4.0 in čas za razvoj strateškega menedžmenta talentov (Yun \& Yeh, 2018, 318). Vključuje proces prepoznavanja, privabljanja, razvijanja, nagrajevanja in zadrževanja talentiranih zaposlenih, ki prispevajo k trajnemu organizacijskemu uspehu in razvoju. Podjetja se zavedajo, da bodo v t. i. vojni za talente uspešne samo tiste organizacije, ki prepoznajo to področje kot ključno in vanj tudi vlagajo ter uporabljajo različne pristope (Collings, 2014, str. 6).

Visokošolsko izobraževanje ima prav tako pomembno vlogo pri razvoju talentov. V zadnjem desetletju se je vloga fakultet začela spreminjati. Z aktivnim sodelovanjem z gospodarstvom pripravljajo izpopolnjene učne načrte, sodobne učne metode pri poučevanju in učenju, ki izpolnjujejo potrebe študentov ter družbe. S sodelovanjem se spodbuja izmenjava znanja, ustvarjajo se dolgoročna partnerstva in priložnosti ter se krepijo inovativnost, podjetništvo, ustvarjalnost. Fakultete morajo študente pripraviti, da razvijejo ključne kompetence za vstop na trg dela, kot so sposobnost reševanja kompleksnih problemov, kritično razmišljanje, prilagodljivost in ustvarjalnost (Yun \& Yeh, 2018, 319-320).

\section{Metoda}

Namen raziskave je bil pridobiti celovit vpogled $\mathrm{v}$ dosedanje raziskave na temo menedžmenta talentov v industriji 4.0, zato smo naredili sistematičen pregled znanstvenih raziskav. Literaturo smo iskali s pomočjo bibliografske zbirke podatkov Scopus. Iskanje je bilo omejeno na naslov prispevka, povzetek, ključne besede. Uporabili smo naslednji besedni zvezi, povezani z Boolovim operaterjem AND (slovensko IN): »talent menedžment» in »human resource menedžment«. Za vključitvene kriterije smo najprej upoštevali, da so bili prispevki objavljeni od leta 2011 naprej, saj se je s tem letom začel uporabljati izraz industrija 4.0. Uporaba iskalnih besed je podala širši nabor literature, in sicer smo dobili 252 zadetkov.

V nadaljevanju smo nabor literature še dodatno omejili, tako da smo izbrali samo zadetke, ki so bili objavljeni s področja poslovanja, menedžmenta in računovodstva ter napisani $\mathrm{v}$ angleškem jeziku, teh zadetkov je bilo 178 . 
Nabor literature se je še ustrezno dodatno skrčil, ko smo vključili dodatni kriterij, in sicer da bomo v pregled izbrali samo recenzirane znanstvene prispevke. Tako smo prišli do končnega vzorca literature za pregled, kar je predstavljalo 132 zadetkov.

Pri pregledu zbrane literature smo uporabili deskriptivno raziskovalno metodo. Osredotočili smo se na naslove in izvlečke raziskav ter vse prebrali. V nadaljnjo obravnavo smo vključili prispevke, ki so obravnavali eno ali več spodaj navedenih tem:

- strateški razvoj upravljanja s kadri,

- povezovanje gospodarstva in izobraževalnih ustanov,

- proces upravljanja s kadri in

- vpliv industrije 4.0 na menedžment talentov.

Po opravljeni selekciji smo izločili 59 prispevkov. Vsebina njihovih povzetkov se ni ujemala s kriteriji za vključitev. Končni vzorec je zajemal 73 člankov. V zadnjem koraku smo povzetke člankov primerjali in ovrednotili. Glede na spoznanja iz obstoječe literature in prebrane povzetke smo nato oblikovali pomembne kategorije na temo menedžmenta talentov. V razpravi smo odkrili potencialne raziskovalne vrzeli in priložnosti za nadaljnje raziskovanje s področja menedžmenta talentov v času industrije 4.0, ki prinaša tudi številne spremembe tudi na področju kadrovskega menedžmenta.

\section{Rezultati}

Na podlagi pridobljene baze prispevkov, ki smo jo dobili po upoštevanju izključitvenih kriterijev, podajamo osnovni opis. Na grafu (Slika 1) lahko vidimo, da se število prispevkov na temo upravljanja talentov na področju kadrovskega menedžmenta od leta 2011 povečuje. Največ prispevkov je bilo objavljenih leta 2016, in sicer 27. To lahko povezujemo s tem, da se je v tem času dogajal največji razmah obdobja digitalizacije in da so se začeli strokovnjaki zavedati pomena razvoja talentov ter intenzivno raziskovati to področje. Leto 2020 še ni zaključeno, zato je število prispevkov znatno nižje. 


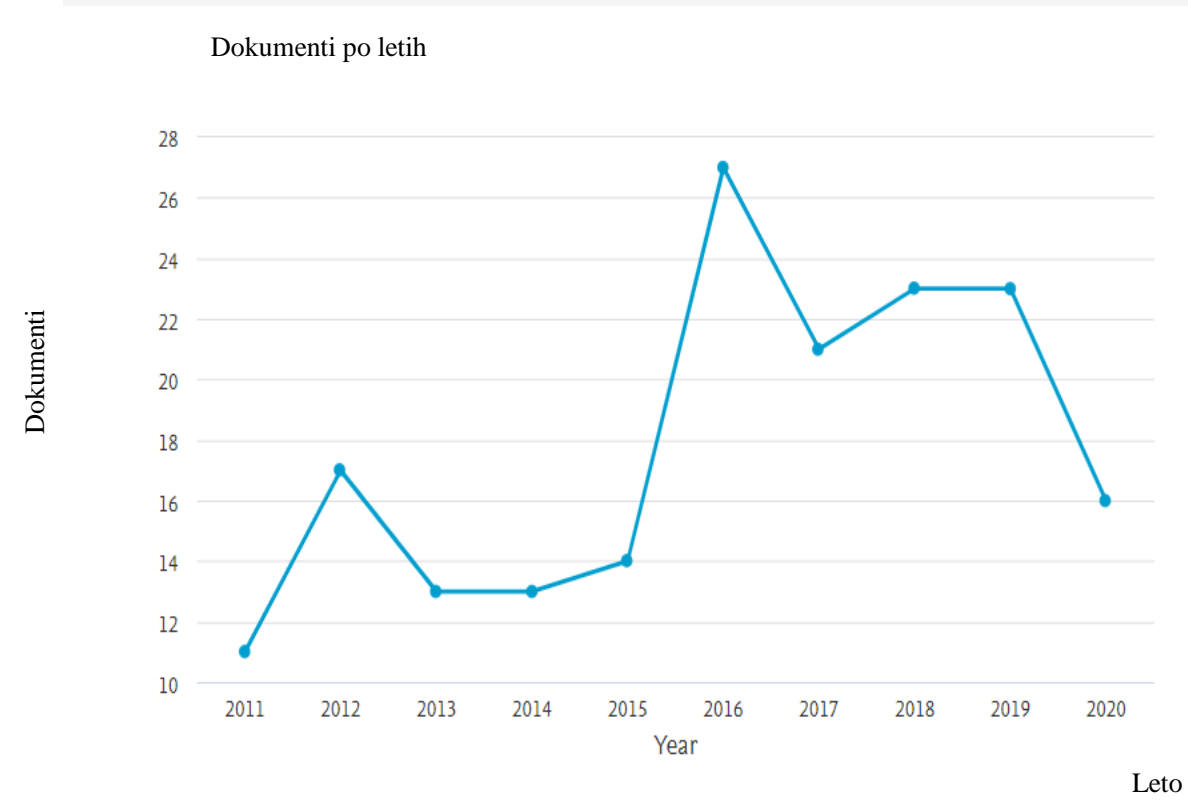

Slika 1. Število prispevkov na temo menedžmenta talentov in kadrovskega menedžmenta od leta 2011 do 2020 (graf pridobljen iz podatkovne baze SCOPUS).

Največ prispevkov je bilo objavljenih s področja ekonomije, menedžmenta in računovodstva, in sicer 178 (57,8 \%), 39 prispevkov je iz področja družboslovnih ved (12,7\%), 37 prispevkov iz področja ekonomije in financ, 15 prispevkov s področja psihologije ter iz ostalih drugih področij.

Od vseh prispevkov je bilo 132 člankov (74,2 \%), 13 konferenčnih prispevkov (7,3\%), 10 knjig (5,6 \%), 10 preglednih člankov (5,6\%), 9 poglavij v knjigi $(5,1 \%)$ in 4 zadetki, ki spadajo pod drugo.

Pri analizi prispevkov smo se osredotočili na 73 prispevkov. Ugotovili smo, da lahko vsebino posameznih člankov razdelimo $\mathrm{v}$ štiri kategorije in na njihove glavne značilnosti, ki so predstavljene v spodnji tabeli. 
Tabela 1. Skupne kategorije literature in opis kategorij.

\begin{tabular}{|c|c|c|}
\hline Kategorija & Opis & Članki \\
\hline $\begin{array}{l}\text { 1. Strateški razvoj } \\
\text { upravljanja s } \\
\text { kadri }\end{array}$ & 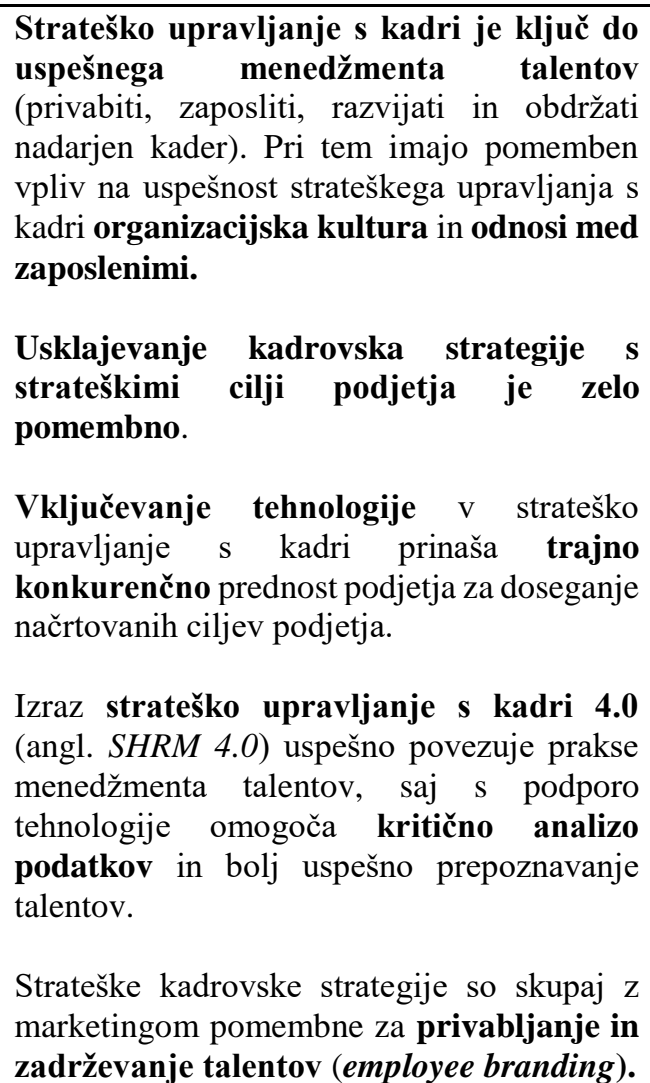 & $\begin{array}{l}\text { Yogalakshmi in Supriya (2020), } \\
\text { Kravariti in Johnston (2020), Wassell } \\
\text { in Bouchard (2020), Al-Abbasi in } \\
\text { Masri (2020), Lotfi, Hasani, in } \\
\text { Esfahani (2020), Vinichenko idr. } \\
\text { (2019), Gardas idr. (2019), Hamad } \\
\text { (2019), Watthanabut (2019), Whysall } \\
\text { et al. (2019), Muyia, Wekullo in } \\
\text { Nafukho (2018), King (2017), } \\
\text { Borisova idr. (2017), Maheshwari idr. } \\
\text { (2017), Fajćíková, Fejfarová in } \\
\text { Urbancová (2016), Lester, Virick, in } \\
\text { Clapp-Smith (2016), Amankwah- } \\
\text { Amoah (2015), Buttiens in } \\
\text { Hondeghem (2015), Sparrow in } \\
\text { Cooper (2014), Jones idr. (2012), }\end{array}$ \\
\hline $\begin{array}{l}\text { 2. Povezovanje } \\
\text { gospodarstva in } \\
\text { izobraževanja }\end{array}$ & $\begin{array}{l}\text { Diplomanti veljajo za ključni vir talentov, } \\
\text { ko se zaposlijo v organizaciji. Fakultete } \\
\text { dajejo premalo pozornosti razvoju tistih } \\
\text { sposobnosti, ki jih posamezniki potrebujejo } \\
\text { za zasedbo delovnih mest v podjetjih. } \\
\text { Delodajalci so označili diplomante kot talent, } \\
\text { t.i. rob, ki mora biti bolj okrepljen s strani } \\
\text { fakultet. Pri prehodu iz fakultete v prakso } \\
\text { imajo pomembno vlogo } \\
\text { usposabljanja in pripravništva. } \\
\text { Diplomanti ne znajo povezati teoretičnih } \\
\text { znanj s praktičnimi, zato morajo fakultete } \\
\text { dati poudarek ciljno usmerjenemu in } \\
\text { izkustvenemu učenju. To poteka tako, da } \\
\text { ustvarijo koncept tovarne, in sicer sklop } \\
\text { izobraževalnih tečajev za npr. vitko } \\
\text { proizvodnjo, s čimer pridobijo ustrezne } \\
\text { poklicne kompetence. Prav tako morajo } \\
\text { raziskati, katere specifične skupine talentov } \\
\text { rabijo v organizacijah (ang. talent pools) in } \\
\text { kako jih bodo izoblikovali. }\end{array}$ & $\begin{array}{l}\text { Ma idr. (2020), Gento, Pimentel in } \\
\text { Pascual (2020), McCracken, Currie in } \\
\text { Harrison (2016) }\end{array}$ \\
\hline $\begin{array}{l}\text { 3. Proces } \\
\text { upravljanja s } \\
\text { kadri (talent } \\
\text { menedžment) }\end{array}$ & $\begin{array}{l}\text { Talentirani zaposleni so redki, dragoceni in } \\
\text { težko nadomestljivi. So vir trajne } \\
\text { konkurenčne prednosti in so ključni za } \\
\text { preživetje v hitro spreminjajočem se svetu. }\end{array}$ & $\begin{array}{l}\text { Do, Le in Phan (2020), Yogalakshm in } \\
\text { Supriya (2020), Wassell in Bouchard } \\
(2020) \text {, Lotfi, Hasani in Esfahani } \\
(2020) \text {, Harun, Mahmood in Othman } \\
\text { (2020), Gento, Pimentel in Pascual } \\
(2020) \text {, Vetráková idr. (2020), Al- }\end{array}$ \\
\hline
\end{tabular}


»nadaljevanje«

4. Industrija 4.0 (tehnološki razvoj)
Definicije talentov so različne glede na lokacije. Več raziskovalcev je ugotovilo, da je prepoznavanje talentov ključnega pomena za organizacije in da to predstavlja vrzel na delovnem mestu.

Uporabljajo se različni pristopi, največ se delodajalci zanašajo na tradicionalno lastno presojo, čeprav je prepoznavanje talentov po standardiziranih postopkih - merilnih lestvicah bistveno bolj strukturirano in objektivno. $\mathrm{Na}$ prepoznavanje talentov vplivajo tudi kulturne norme, simboli in prakse.

Menedžment talentov ima svoj vpliv na vseh procesih organizacije, zato je v 21. stoletju eno najbolj raziskanih področij. Nekateri raziskovalci menijo, da so ti pogledi preveč menedžersko usmerjeni. Vpliva na t. i. organizacijsko inteligenco.

Prakse upravljanja s talenti morajo biti pravične, ciljno usmerjene in morajo imeti ustrezen vpliv na zavzetost zaposlenih, podkrepljene $\mathrm{z}$ močnimi medosebnimi odnosi, ki jih povezujejo $\mathrm{z}$ uspehom podjetja. Vse to vpliva na večjo produktivnost in uspeh podjetja. Strateško usklajene in etično visokozmogljive organizacijske kulture imajo visok vpliv na privabljanje ter zadrževanje talentov, kar pa vpliva tudi na visoko zavzetost med zaposlenimi in njihovo motivacijo za delo.

Menendžment talentov ima pomembno vlogo pri nasledstvih, predvsem $\mathrm{v}$ času globalizacije, ko primanjkuje usposobljenih vodstvenih talentov. Izziv predstavlja prepoznavanje in razvoj globalnih vodij. Učinkovitost praks menedžmenta talentov pozitivno vpliva na razvoj vodstvenih kompetenc.

Razvoj in zadrževanje talentov naj se izvajata preko bazena talentov. Prepoznani talenti morajo imeti občutek prepoznavnosti in biti cenjeni, treba jim je omogočiti usposabljanje ter razvoj. Organizacijska podpora $\mathrm{s}$ kariernimi priložnostmi ne zadržuje talentov. Pri tem je pomembna vpeljava strategije menedžmenta talentov in ustvarjanje t. i. ozračja za nadarjene, kjer lahko razvijejo svoj potencial v povezavi $\mathrm{s}$ strategijo podjetja. Prakse menedžmenta talentov se razlikujejo in pomembno je, da se prilagodijo lokalnemu okolju.

Industrija 4.0 zahteva spremembe pri strateškem upravljanju s kadri, saj $s$ hitrim tehnološkim razvojem ustvarja
Abbasi in Masri (2020), Pauli in Pocztowski (2019), Guan in Huan (2019), Murillo in King (2019), Muskat idr. (2019), Vinichenko idr. (2019), Gardas idr. (2019),

Khoreva in Kostanek (2019), O'Connor in Crowley-Henry (2019), Pantouvakis in Karakasnaki (2019), Whysall, Owtram in Brittain (2019), Crowley-Henry, Benson in Al Ariss (2019), Neece in Wulf (2019), Watthanabut (2019), MuratbekovaTouron, Kabalina in Festing (2018), Ambrosius (2018), King (2017), Sinclair-Maragh, Jacobs-Gray in Brown-Roomes (2017), Suseno in Pinnington (2017), Borisova idr. (2017), Kadyrbekova (2017), Saddozai idr. (2017), Fogarassy, Szabo in Poor (2017), Khoreva,Vaiman in Van Zalk (2017), Maheshwari idr. (2017), Malik, Singh in Chan (2017), Tarim (2016), Story, Castanheira in Hartig (2016), McDonnell, Gunnigle in Lavelle (2016), García-Carbonell, Martín-Alcázar, Sánchez-Gardey (2015), Foster (2015), Gooderham idr. (2015), Othman in Sumardi (2014), Liu in Pearson (2014), Hohenstein, Feisel in Hartmann (2014), Boudreau (2014), Schmidt, Mansson in Dolles (2013), Festing, Schäfer in Scullion, (2013), Nankervis (2013), Macfarlane idr. (2012), Guerci in Solari (2012)

Do, Le in Phan (2020), Whysall, Owtram in Brittain (2019), Chang in 


\begin{tabular}{l|l|l} 
»nadaljevanje« & $\begin{array}{l}\text { razkorak med trenutnimi kompetencami } \\
\text { zaposlenih in zahtevami delovnih mest v } \\
\text { prihodnosti. }\end{array}$ & $\begin{array}{l}\text { Yeh (2018), Connell in Stanton (2014), } \\
\text { Corsello (2012) }\end{array}$ \\
$\begin{array}{l}\text { Tehnologija omogoča analitiko zaposlenih } \\
\mathbf{z} \text { uporabo velike količine podatkov, } \\
\text { umetne inteligence, interneta stvari, kar } \\
\text { omogoča, da je strategija upravljanja s kadri } \\
\text { bolj trdna. }\end{array}$ & $\begin{array}{l}\text { Industrija 4.0 z avtomatizacijo ne vpliva } \\
\text { na zmanjšanje delovnih mest, ampak } \\
\text { zahteva prilagoditev strategij } \\
\text { menedžmenta talentov, ki naj bodo bolj } \\
\text { dinamične, sistemsko orientirane s } \\
\text { poglobljenim pogledom za naprej. }\end{array}$ & \\
\hline
\end{tabular}

\section{Razprava}

V zadnjih desetih letih se je zvrstilo veliko raziskav na področju menedžmenta talentov, vendar je raziskav na temo menedžmenta talentov v industriji 4.0 zelo malo. Iz pregleda literature v Scopus bibliografski bazi sta na to temo bila do danes objavljena samo 2 članka. Na začetku raziskave smo si zastavili raziskovalno vprašanje, in sicer kakšne spremembe prinaša industrija $4.0 \mathrm{v}$ praski menedžmenta talentov. Po pregledu literature ugotavljamo, da prinaša industrija 4.0 spremembe predvsem na štirih področjih, to je v procesu strateškega upravljanja s kadri, v procesih upravljanja $\mathrm{s}$ talenti, $\mathrm{v}$ povezovanju gospodarstva $\mathrm{z}$ izobraževalnimi ustanovami in vključevanju tehnologije $\mathrm{v}$ razmahu industrije 4.0. Na področju strateškega upravljanja s kadri prinaša vključevanje tehnologije $\mathrm{v}$ strateško upravljanje s kadri trajno konkurenčno prednost podjetja za doseganje načrtovanih ciljev. Pri privabljanju in pridobivanju talentiranih posameznikov se trudijo predvsem z gradnjo blagovne znamke, učinkovitim oglaševanjem, družbeno odgovornostjo podjetja in $\mathrm{s}$ sodelovanjem na različnih poklicnih sejmih.

Vloga strateške kadrovske službe postaja vse bolj pomembna pri strateških odločitvah podjetja. Potrebe industrije 4.0 se pojavljajo na področju upravljanja talentov, kjer je za razliko od preteklosti ključno gonilo znanje oz. sposobnosti posameznika, da se prilagodi hitrim tehnološkim spremembam. Industrija 4.0. z avtomatizacijo in robotizacijo spreminja način dela, vendar ne zmanjšuje delovnih mest. Povzročila je velik razkorak med trenutnimi sposobnostmi zaposlenih v primerjavi z zahtevami prihodnjih delovnih mest. Novi zaposleni morajo za uspeh na delovnem mestu spremeniti mišljenje in imeti dovolj različnih ter ustreznih kompetenc, ki pa jih med formalnim izobraževanjem ne pridobijo. Te kompetence so kritično mišljenje, povezovanje, komunikacija in ciljna usmeritev. Podjetja tako ne potrebujejo več ozko usmerjenih inženirjev, ampak morajo imeti kombinacijo več kompetenc.

Industrija 4.0 omogoča analitiko velikih količin podatkov o kadrih, s čimer se lahko podjetja hitreje prilagajajo spremembam in bolj analitično pristopijo pri zaposlovanju oz. odkrivanju talentov znotraj podjetja. Ključnega pomena v praksi menedžmenta je tako prepoznavanje, razvijanje in 
zadrževanje talenta. Podjetja morajo v času industrije 4.0 razviti nove pristope menedžmenta talentov, ki morajo biti bolj dinamični in usmerjeni za prihodnost. Prepoznavanje talentov mora potekati objektivno in po standardiziranem postopku ter ne več po lastni presoji kot je bila praksa v preteklosti. Pri razvijanju talentov znotraj podjetij se podjetja poslužujejo različnih usposabljanj. Podjetja potrebujejo talentirane zaposlene, ki bodo znali delati s tehnologijo na področju vitke proizvodnje, interneta stvari (IoT), dela v oblaku in velikih podatkov, ki so značilni za industrijo 4.0. Kljub temu da lahko tehnologija nadomesti človeško delo, še za zdaj ne more nadomestiti človeškega znanja, kritičnega mišljenja, ustvarjalnosti in drugih lastnosti.

Države veliko investirajo v razvoj talentov, tako da razvijajo različne državne politike, ustanavljajo kompetenčne centre, spodbujajo usposabljanja znotraj podjetij ipd. Zato je povezovanje gospodarstva in izobraževanja četrto področje, ki ga je treba nadgraditi zaradi vpliva industrije 4.0. Fakultete imajo pomembno vlogo pri razvoju talentov. Pomembno je, da fakultete prepoznajo ključne skupine talentov t. i. bazene talentov, ki jih nato usposobijo za nastop na trg dela. Študentje morajo znati povezovati teoretično s praktičnim znanjem. Delodajalci jih privabljajo tako, da jim nudijo štipendije ali različna usposabljanja, startupe, teme in pomoč pri zaključnih nalogah (Whysall et al., 2019).

\section{Zaključek}

Menedžment talentov je eno izmed najbolj raziskovanih segmentov na področju upravljanja s kadri v 21. stoletju. S pregledom literature smo si ustvarili kritičen vpogled, kako industrija 4.0 vpliva na spremembe praks menedžmenta talentov in kakšne priložnosti ter izzive predstavlja za strateško upravljanje s kadri. Konkurenčno prednost podjetja ustvarjajo talentirani zaposleni. Ustrezno upravljanje s kadri vključuje prepoznavanje, razvijanje in zadrževanje talentov. Potrebna je prava organizacijska kultura, znotraj katere se ustvari primerno okolje, v katerem se bodo talentirani posamezniki dobro počutili in bodo tako pri svojem delu tudi ustvarjalni.

Raziskava je bila omejena na razpoložljive predhodne raziskave, iz katerih smo naredili sistematičen pregled po kategorijah. Iz naše raziskave smo ugotovili, da menedžment talentov pozitivno vpliva tudi na razvoj vodstvenih kompetenc. Glede na to, da se velike multinacionalke soočajo s težavami za globalna nasledstva na vodilnih položajih, predlagamo nadaljnje raziskave na področju upravljanja talentov vrhnjega menedžmenta. Ugotoviti je treba, kakšne kompetence bi moral razviti vodstveni kader v času, ki ga narekuje industrija 4.0, in kakšne inovativne prakse upravljanja s talenti bi bile potrebne. 


\section{Reference}

1. Al Ariss, A., Cascio, W. F., \& Paauwe, J. (2014). Talent menedžment: Current theories and future research directions. Journal of World Business, 49(2), 173-179.

2. Al-Abbasi, S., \& Masri, H. (2020). Optimizing faculty talents through identifying entrepreneurial champions: an ELECTRE IV approach. Menedžment Decision. https://doi.org/10.1108/MD-092019-1305

3. Amankwah-Amoah, J. (2015). An integrative review of the antecedents and consequences of lateral hiring. Journal of Menedžment Development, 34(7), 754-772. https://doi.org/10.1108/JMD-01-2014-0007

4. Ambrosius, J. (2018). Strategic Talent Menedžment in Emerging Markets and Its Impact on Employee Retention: Evidence from Brazilian MNCs. Thunderbird International Business Review, 60(1), 53-68. https://doi.org/10.1002/tie.21799

5. Belak, J., Duh, M.. \& Štrukelj, T. (2017). The higher education in Slovenia v M. Szafranski, M. Golinski and H. Simi, The acceleration of development of transversal competences, Kokkola:Centria University of Applied Sciences, 2017, ISBN 9789527173268.

6. Benešová, A. and Tupa, J. (2017). Requirements for education and qualification of people in Industry 4.0. Procedia Manufacturing, 11, 2195-2202-

7. Borisova, O. N., Silayeva, A. A., Saburova, L. N., Belokhvostova, N. V., \& Sokolova, A. P. (2017). Talent menedžment as an essential element in a corporate personnel development strategy. Academy of Strategic Menedžment Journal, 16(Special Issue), 31-46.

8. Boudreau, J. W. (2013). Appreciating and 'retooling'diversity in talent menedžment conceptual models: A commentary on "The psychology of talent menedžment: A review and research agenda". human Resource menedžment Review, 23(4), 286-289. https://doi.org/10.1016/j.hrmr.2013.08.001

9. Buttiens, D., \& Hondeghem, A. (2015). Strategic choices regarding talent menedžment in the Flemish public sector. Society and Economy, 37(1), 49-72. https://doi.org/10.1556/SocEc.37.2015.1.3

10. Chang, Y.-H., \& Yeh, Y.-J. Y. (2018). Industry 4.0 and the need for talent: a multiple case study of Taiwan's companies. International Journal of Product Development, 22(4), 247-275. 10.1504/IJPD.2018.091150.

11. Collings, D. G. (2014). Toward mature talent menedžment: Beyond shareholder value. Human Resource Development Quarterly, 25(3), 301-319. https://doi.org/10.1002/hrdq.21198

12. Connell, J., \& Stanton, P. (2014). Skills and the role of HRM: Towards a research agenda for the Asia Pacific region. Asia Pacific Journal of Human Resources, 52(1), 4-22. https://doi.org/10.1111/1744-7941.12021

13. Corsello, J. (2012). Maximizing talent menedžment through the cloud: New technologies offer opportunities to develop skills and careers. Human Resource Menedžment International Digest, 20(4), 27-30. https://doi.org/10.1108/09670731211233339

14. Crowley-Henry, M., Benson, E. T., \& Al Ariss, A. (2019). Linking Talent Menedžment to Traditional and Boundaryless Career Orientations: Research Propositions and Future Directions. European Menedžment Review, 16(1), 5-19. https://doi.org/10.1111/emre.12304

15. Do, T. D., Le, L. C., \& Phan, T. T. (2020). Factors affecting talent retention: Case study of universities in ho chi minh city. International Journal of Entrepreneurship, 24(1).

16. Fajčíková, A., Fejfarová, M., \& Urbancová, H. (2016). Employee Development by Talent Menedžment. Scientific papers of the University of Pardubice. Series D, Faculty of Economics and Administration. 38/2016.

17. Festing, M., Schäfer, L., \& Scullion, H. (2013). Talent menedžment in medium-sized German companies: An explorative study and agenda for future research. International Journal of Human Resource Menedžment, 24(9), 1872-1893. https://doi.org/10.1080/09585192.2013.777538

18. Fogarassy, C., Szabo, K., \& Poor, J. (2017). Critical issues of human resource planning, performance evaluation and long-term development on the central region and non-central areas: Hungarian case study for investors. International Journal of Engineering Business Menedžment, 9, 1-9. https://doi.org/10.1177/1847979016685338 
19. Foster, C. L. (2015). Managing the flow of talent through organizations - a boundary-less model. Development and Learning in Organizations, 29(1), 15-19. https://doi.org/10.1108/DLO-062014-0045

20. Gallardo-Gallardo, E., Nijs, S., Dries, N., \& Gallo, P. (2015). Towards an understanding of talent menedžment as a phenomenon-driven field using bibliometric and content analysis. Human Resource Menedžment Review, 25(3), 264-279. https://doi.org/10.1016/j.hrmr.2015.04.003

21. Gallardo-Gallardo, E., Dries, N., \& González-Cruz, T. F. (2013). What is the meaning of 'talent'in the world of work?. Human Resource Menedžment Review, 23(4), 290-300. 10.1016/j.hrmr.2013.05.002.

22. García-Carbonell, N., Martín-Alcázar, F., \& Sánchez-Gardey, G. (2015). Determinants of top menedžment's capability to identify core employees. BRQ Business Research Quarterly, 18(2), 69-80. https://doi.org/10.1016/j.brq.2014.07.002

23. Gardas, B. B., Mangla, S. K., Raut, R. D., Narkhede, B., \& Luthra, S. (2019). Green talent menedžment to unlock sustainability in the oil and gas sector. Journal of Cleaner Production, 229, 850-862. https://doi.org/10.1016/j.jclepro.2019.05.018

24. Gento, A. M., Pimentel, C., \& Pascual, J. A. (2020). Lean school: an example of industryuniversity collaboration. Production Planning \& Control, 1-16. https://doi.org/10.1080/09537287.2020.1742373

25. Gooderham, P. N., Morley, M. J., Parry, E., \& Stavrou, E. (2015). National and firm-level drivers of the devolution of HRM decision making to line managers. Journal of International Business Studies, 46(6), 715-723. https://doi.org/10.1057/jibs.2015.5

26. Guan, X.-H., \& Huan, T.-C. (2019). Talent menedžment for the proactive behavior of tour guides. International Journal of Contemporary Hospitality Menedžment, 31(10), 4043-4061. https://doi.org/10.1108/IJCHM-07-2018-0596

27. Guerci, M., \& Solari, L. (2012). Talent menedžment practices in italy-implications for human resource development. Human Resource Development International, 15(1), 25-41. https://doi.org/10.1080/13678868.2011.647461

28. Hamad, Z. M. M. (2019). Talent menedžment as a facilitator of organizational intelligence. Menedžment Science Letters, 9(6), 809-822. https://doi.org/10.5267/j.msl.2019.3.007

29. Harun, N. H., Mahmood, N. H., \& Othman, S. A. (2020). The effect of talent menedžment factors on teacher's leadership at the secondary schools. Menedžment Science Letters, 10(1), 225-234. https://doi.org/10.5267/j.msl.2019.7.039

30. Hohenstein, N.-O., Feisel, E., \& Hartmann, E. (2014). Human resource menedžment issues in supply chain menedžment research: A systematic literature review from 1998 to 2014. International Journal of Physical Distribution and Logistics Menedžment, 44(6), 434-463. https://doi.org/10.1108/IJPDLM-06-2013-0175

31. Jones, J. T., Whitaker, M., Seet, P.-S., \& Parkin, J. (2012). Talent menedžment in practice in australia: Individualistic or strategic? An exploratory study. Asia Pacific Journal of Human Resources, 50(4), 399-420. https://doi.org/10.1111/j.1744-7941.2012.00036.x

32. Kadyrbekova, U. A. (2017). Prospects for the use of the concept and methods of talent menedžment in the practice of public service (on the materials of the Republic of Kazakhstan). Revista ESPACIOS, 38(48).

33. Khoreva, V., \& Kostanek, E. (2019). Evolving talent menedžment patterns and challenges in Russia and Kazakhstan: Investigating employer perspective. Baltic Journal of Menedžment, 14(3), 411-426. https://doi.org/10.1108/BJM-09-2018-0340

34. Khoreva, V., Vaiman, V., \& Van Zalk, M. (2017). Talent menedžment practice effectiveness: investigating employee perspective. Employee Relations, 39(1), 19-33. https://doi.org/10.1108/ER-01-2016-0005

35. Kiesel, M., \& Wolpers, M. (2015, October). Educational challenges for employees in projectbased Industry 4.0 scenarios. In Proceedings of the 15th International Conference on Knowledge Technologies and Data-driven Business (pp. 1-4).

36. King, K. A. (2017). The talent climate: Creating an organisational context supportive of sustainable talent development through implementation of a strong talent system. Journal of Organizational Effectiveness, 4(4), 298-314. https://doi.org/10.1108/JOEPP-03-2017-0023 
37. Muskat, B., Lockstone-Binney, L., Ong, F., \& Andresen, M. (2019). Talent in hospitality entrepreneurship: A conceptualization and research agenda. International Journal of Contemporary Hospitality Menedžment, 31(10), 3899-3918. https://doi.org/10.1108/IJCHM-102018-0867

38. Kravariti, F., \& Johnston, K. (2020). Talent menedžment: a critical literature review and research agenda for public sector human resource menedžment. Public Menedžment Review, 22(1), 75-95. https://doi.org/10.1080/14719037.2019.1638439

39. Lester, G. V., Virick, M., \& Clapp-Smith, R. (2016). Harnessing global mindset to positively impact advances in global leadership through international human resource menedžment practices. In Advances in global leadership. Emerald Group Publishing Limited. https://doi.org/10.1108/S1535-120320160000009010

40. Liu, Y., \& Pearson, C. A. L. (2014). The importance of talent menedžment: A study of Chinese organisations. Journal of Chinese Economic and Foreign Trade Studies, 7(3), 153-172. https://doi.org/10.1108/JCEFTS-12-2014-0026

41. Lotfi, A., Hasani, A., \& Esfahani, S. A. (2020). Performance assessment of talent menedžment system via using system dynamic approach and scenario planning (case study: Iran Falat-Qhare Oil Company). International Journal of Productivity and Quality Menedžment, 29(1), 62-93. https://doi.org/10.1504/IJPQM.2020.104539

42. Ma, C., Ren, L., Chen, P., \& Hu, R. X. (2020). Institute-Hotel Coordinating Barriers to Early Career Menedžment-Hoteliers' Accounts. Journal of China Tourism Research, 16(2), 297-317. https://doi.org/10.1080/19388160.2019.1581677

43. Macfarlane, F., Duberley, J., Fewtrell, C., \& Powell, M. (2012). Talent menedžment for NHS managers: Human resources or resourceful humans? Public Money and Menedžment, 32(6), 445452. https://doi.org/10.1080/09540962.2012.728786

44. Maheshwari, V., Gunesh, P., Lodorfos, G., \& Konstantopoulou, A. (2017). Exploring HR practitioners' perspective on employer branding and its role in organisational attractiveness and talent menedžment. International Journal of Organizational Analysis, 25(5), 742-761. https://doi.org/10.1108/IJOA-03-2017-1136

45. Malik, A. R., Singh, P., \& Chan, C. (2017). High potential programs and employee outcomes: The roles of organizational trust and employee attributions. Career Development International, 22(7), 772-796. https://doi.org/10.1108/CDI-06-2017-0095

46. McCracken, M., Currie, D., \& Harrison, J. (2016). Understanding graduate recruitment, development and retention for the enhancement of talent menedžment: sharpening 'the edge' of graduate talent. International Journal of Human Resource Menedžment, 27(22), 2727-2752. https://doi.org/10.1080/09585192.2015.1102159

47. McDonnell, A., Gunnigle, P., Lavelle, J., \& Lamare, R. (2016). Beyond managerial talent: 'key group' identification and differential compensation practices in multinational companies. International Journal of Human Resource Menedžment, 27(12), 1299-1318. https://doi.org/10.1080/09585192.2015.1075571

48. Muratbekova-Touron, M., Kabalina, V., \& Festing, M. (2018). The phenomenon of young talent menedžment in Russia-A context-embedded analysis. Human Resource Menedžment, 57(2), 437-455. https://doi.org/10.1002/hrm.21860

49. Murillo, E., \& King, C. (2019). Why do employees respond to hospitality talent menedžment: An examination of a Latin American restaurant chain. International Journal of Contemporary Hospitality Menedžment, 31(10), 4021-4042. https://doi.org/10.1108/IJCHM-10-2018-0871

50. Muyia, M. H., Wekullo, C. S., \& Nafukho, F. M. (2018). Talent Development in Emerging Economies Through Learning and Development Capacity Building. Advances in Developing Human Resources, 20(4), 498-516. https://doi.org/10.1177/1523422318803089

51. Nankervis, A. R. (2013). "Building for the future?" Government and industry responses to the challenges of talent menedžment in China following the GFC. Asia Pacific Business Review, 19(2), 186-199. https://doi.org/10.1080/13602381.2013.767635

52. Neece, M. R., \& Wulf, S. A. (2019). Selecting Excellence: A Data-Driven Process to Hire Top Performance Engineers with Greater Speed and Certainty. IEEE Engineering Menedžment Review, 47(1), 11-16. https://doi.org/10.1109/EMR.2019.2901682 
53. O’Connor, E. P., \& Crowley-Henry, M. (2019). Exploring the Relationship Between Exclusive Talent Menedžment, Perceived Organizational Justice and Employee Engagement: Bridging the Literature. Journal of Business Ethics, 156(4), 903-917. https://doi.org/10.1007/s10551-017$3543-1$

54. Othman, R. B., \& Sumardi, W. A. (2014). Talent menedžment at Steelcase Manufacturing, Malaysia: managing high performance. Emerald Emerging Markets Case Studies, 4(6), 1-10. https://doi.org/10.1108/EEMCS-05-2013-0051

55. Pantouvakis, A., \& Karakasnaki, M. (2019). Exploring the links between talent philosophies and talent menedžment in service organizations. Industrial and Commercial Training, 51(4), 277-286. https://doi.org/10.1108/ICT-03-2019-0026

56. Pauli, U., \& Pocztowski, A. (2019). Talent menedžment in SMEs: An exploratory study of Polish companies. Entrepreneurial Business and Economics Review, 7(4), 199-218. https://doi.org/10.15678/EBER.2019.070412

57. Saddozai, S. K., Hui, P., Akram, U., Khan, M. S., \& Memon, S. (2017). Investigation of talent, talent menedžment, its policies and its impact on working environment. Chinese Menedžment Studies, 11(3), 538-554. https://doi.org/10.1108/CMS-10-2016-0206

58. Schmidt, C., Mansson, S., \& Dolles, H. (2013). Managing talents for global leadership positions in MNCs: Responding to the challenges in China. Asian Business and Menedžment, 12(4), 477496. https://doi.org/10.1057/abm.2013.11

59. Schwab, K. (2016). Četrta industrijska revolucija, World Economic Forum, Ženeva; slovenski prevod: Igor Pauletič

60. Sinclair-Maragh, G., Jacobs-Gray, N., \& Brown-Roomes, N. (2017). A case of talent menedžment practices in motivating fast food service employees. Emerald Emerging Markets Case Studies, 7(3), 1-16. https://doi.org/10.1108/EEMCS-07-2016-0153

61. Sparrow, P., \& Cooper, C. (2014). Organizational effectiveness, people and performance: new challenges, new research agendas. Journal of Organizational Effectiveness, 1(1), 2-13. https://doi.org/10.1108/JOEPP-01-2014-0004

62. Story, J., Castanheira, F., \& Hartig, S. (2016). Corporate social responsibility and organizational attractiveness: Implications for talent menedžment. Social Responsibility Journal, 12(3), 484-505. https://doi.org/10.1108/SRJ-07-2015-0095

63. Suseno, Y., \& Pinnington, A. H. (2017). The war for talent: human capital challenges for professional service firms. Asia Pacific Business Review, 23(2), 205-229. https://doi.org/10.1080/13602381.2017.1287830

64. Tarim, T. B. (2016). Managing technical professionals: Talent menedžment. IEEE Engineering Menedžment Review, 44(3), 11-12. https://doi.org/10.1109/EMR.2016.2595138

65. Vetráková, M., Šimočková, I., Kubal'a, J., \& Malachovský, A. (2020). How to establish talented employees in Slovak companies. Periodica Polytechnica Social and Menedžment Sciences, 28(1), 29-37. https://doi.org/10.3311/PPso.13269

66. Vinichenko, M. V., Rybakova, M. V., Chulanova, O. L., Kuznetsova, I. V., Makushkin, S. A., \& Lobacheva, A. S. (2019). Using natural and artificial intelligence in the talent menedžment system. International Journal of Recent Technology and Engineering, 8(3), 7417-7423. https://doi.org/10.35940/ijrte.C6152.098319

67. Wassell, S., \& Bouchard, M. (2020). Rebooting strategic human resource menedžment: Integrating technology to drive talent menedžment. International Journal of Human Resources Development and Menedžment, 20(2), 93-113. https://doi.org/10.1504/IJHRDM.2020.106275

68. Watthanabut, B. (2019). From HR 4.0 to better supply chain flexibility: Role of talent on boarding and a development in Thailand. International Journal of Supply Chain Menedžment, 8(5), 804815.

69. Whysall, Z., Owtram, M., \& Brittain, S. (2019). The new talent menedžment challenges of Industry 4.0. Journal of Menedžment Development, 38(2), 118-129. https://doi.org/10.1108/JMD06-2018-0181

70. Yogalakshmi, J. A., \& Supriya, M. V. (2020). Talent quotient: development and validation of a measurement scale. Journal of Menedžment Development, 39(3), 306-323. https://doi.org/10.1108/JMD-03-2019-0075 
Janja Polenšek Davidovski je doktorska študentka na Fakulteti za menedžment Univerze na Primorskem. Zaposlena je na področju kadrov, kjer se ukvarja $z$ razvojem kadrov in njihovih potencialov, vodi ali sodeluje pri kadrovskih ter drugih organizacijskih projektih. Njeni raziskovalni interesi obsegajo področja menedžmenta talentov, zdravja na delovnem mestu, izobraževanja in tehnologije.

Borut Likar, doktor elektrotehniških znanosti, je redni profesor in znanstveni svétnik na Fakulteti za menedžment. Njegova raziskovalna področja so menedžment ustvarjalnosti, RRa, inovativnosti in tehnologij; tako v povezavi z gospodarstvom kot s šolskim sistemom. Je avtor številnih izvirnih znanstvenih in strokovnih del ter mnogih patentov in tržno uspešnih inovacij. V svoji bibliografiji ima več kot 500 zapisov. Je prejemnik več domačih in mednarodnih nagrad za svoje delo, tako s področja raziskovalnega dela kot konkretnih inovacij. Aktiven je tudi kot ocenjevalec projektov EU, vabljen predavatelj, recenzent znanstvenih publikacij in urednik mednarodnih znanstvenih konferenc in publikacij. Med vrsto vabljenih predavanj so bila še posebno odmevna tista na sedežu Organizacije združenih narodov v Ženevi in kar v dve v Evropskem parlamentu. Je tudi amaterski fotograf, pri čemer ga zanimajo predvsem ustvarjalni pristopi, in pisec aforizmov.

Maja Meško je redna profesorica menedžmenta na Fakulteti za menedžment Univerze na Primorskem. Doktorirala je na področju kineziologije, naslov njene doktorske disertacije je Definiranje nekaterih gibalnih sposobnosti in psiholoških značilnosti slovenskih vojaških pilotov. Njeni raziskovalni interesi obsegajo področja menedžmenta, psihologije v menedžmentu, zdravja na delovnem mestu ter vodenja. Sodelovala je in še sodeluje tudi pri različnih projektih. Je avtorica in soavtorica številnih znanstvenih ter strokovnih člankov.

$$
* * *
$$

\section{Abstract: Talent Management for Industry 4.0}

Research Question (RQ): How much research has been published on Talent management and Industry 4.0, since the concept first appeared in 2011? What changes does the Industry 4.0 talent management practice bring?

Purpose: The purpose of the research is conducting a literature review, i.e. scientific articles, scientific conference papers and chapters in scientific monographs, in the field of talent management in Industry 4.0, and making a classification of their characteristics.

Method: For the purpose of the study we did a systemic literature review of contributions published on Scopus database.

Results: Not a lot of contributions have been published on talent management and Industry 4.0 since 2011. The articles published address the competencies that key personnel will need in the future, the challenges of the education system because of the changes required by Industry 4.0, and the importance of talent for organizations of the future.

Organization: A review of the scientific literature in the field of talent management and Industry 4.0 provides organizations with useful information to develop HR strategies.

Society: Talents represent one of the key sources of Industry 4.0 development. Talents in society are essential, as they bring knowledge to a changing environment, as well as competitive advantages for organizations.

Originality: The survey provides an in-depth insight into the changes that Industry 4.0 brings to the talent management practice.

Limitations / further research: The limitations of a literature review of this nature is the complete reliance on previously published research and the availability of these studies.

Keywords: management, talents, talent management, Industry 4.0. 
Revija za univerzalno odličnost / Journal of Universal Excellence

Članek / Article

September 2020, leto / year 9, številka / number 3, str. / pp. 239-254.

Copyright (c) Janja POLENŠEK DAVIDOVSKI, Maja MEŠKO, Borut LIKAR

\section{(c) (i) (2)}

Creative Commons License

This work is licensed under a Creative Commons Attribution-ShareAlike 4.0 International License. 